\title{
Body Resistance and Productive Performances of Crossbred Local Chicken Fed Inulin of Dahlia Tubers
}

\author{
N. Fajrih*, N. Suthama, \& V. D. Yunianto \\ Faculty of Animal Science and Agriculture, Diponegoro University \\ Kampus drh. Soejono Koesoemowardoyo, Tembalang Semarang 50275, Indonesia \\ (Received 07-05-2014; Reviewed 02-06-2014; Accepted 10-07-2014)
}

\begin{abstract}
The research was aimed to examine the role of inulin as a prebiotic derived from dahlia flower tuber in the form of powder and extract as a prebiotic on body immunity of crossbred local chicken. The research was assigned in a completely randomized design with 7 treatments and 4 replications (10 birds each). The treatments applied were T0: basal ration, T1: ration $+0.4 \%$ powder, T2: ration + $0.8 \%$ powder, $\mathrm{T} 3$ : ration $+1.2 \%$ powder, $\mathrm{T} 4$ : ration $+0.39 \%$ extract, $\mathrm{T} 5$ : ration $+0.78 \%$ extract, $\mathrm{T} 6$ : ration $+1.17 \%$ extract. The birds were reared for conditioning from day 1 until day 21 , and dietary treatment was given thereafter until $11 \mathrm{wk}$ of age. The data were statistically analyzed according to ANOVA and continued to Duncan test at the level of $5 \%$ probability. The results showed that feeding inulin in the form of powder or extract significantly $(P<0.05)$ increased the weight of bursa fabricius and $B W G$, but it decreased meat fat and cholesterol while the weight of spleen was not affected. In conclusion, the higher levels of feeding inulin in the form of powder at $1.2 \%$ (T3) and extract at $1.17 \%$ (T6), improves health status, performances and product quality of crossbred local chicken.
\end{abstract}

Key words: crossbred local chicken, inulin of dahlia tuber, health status, meat fat profile, body weight gain

\section{ABSTRAK}

Penelitian bertujuan untuk mengkaji peranan inulin sebagai prebiotik yang bersumber dari umbi bunga dahlia dalam bentuk tepung dan ekstrak terhadap ketahanan tubuh ayam lokal persilangan. Penelitian menggunakan rancangan acak lengkap dengan 7 perlakuan dan 4 ulangan (masing-masing 10 ekor). Perlakuan meliputi T0: ransum basal, T1: ransum $+0,4 \%$ tepung, T2: ransum $+0,8 \%$ tepung, T3: ransum $+1,2 \%$ tepung, T4: ransum $+0,39 \%$ ekstrak, T5: ransum $+0,78 \%$ ekstrak, T6: ransum $+1,17 \%$ ekstrak. Ayam dipelihara dari umur 1 sampai 21 hari sebagai periode penyesuaian, dan selanjutnya diberi ransum perlakuan sampai umur 11 minggu. Data dianalisis varian dan dilanjutkan uji Duncan pada probabilitas $5 \%$. Hasil penelitian menunjukkan bahwa pemberian inulin dalam bentuk tepung maupun ekstrak nyata $(P<0,05)$ meningkatkan bobot bursa fabrisius dan PBB, tetapi menurunkan kadar lemak dan kolesterol daging, sedangkan bobot limpa sama. Kesimpulan penelitian bahwa semakin tinggi level pemberian inulin baik dalam bentuk tepung sampai $1,2 \%$ (T3) maupun ekstrak sampai 1,17\% (T6), semakin meningkatkan status kesehatan, performa dan kualitas produk ayam lokal persilangan.

Kata kunci: ayam lokal persilangan, inulin umbi dahlia, status kesehatan, profil lemak daging, pertambahan bobot badan

\section{INTRODUCTION}

Crossbred local chicken or known as "superior" native chicken is a descendant of male native chickens and female modern laying hens. This crossbred local chicken

*Corresponding author:

E-mail: nunu.nuru191@gmail.com can be slaughtered for market at the age of $60 \mathrm{~d}$ because the growth rate is similar to that of pure native chicken at the age of 5 mo. Growth promoting additive for native chickens and also crossbred filial is still needed to speed up growth rate in order to achieve a higher productive efficiency. Providing feed additive such as antibiotics, drugs or hormones is the strategy that can be applied to improve growth or productive ability. However, such compounds of additive nowadays cannot be 
recommended to be applicably maintained due to the problems of residue in the poultry product that harmful for the consumer's health and causing other negative impacts. Therefore, it is important to overcome the problem by selecting alternative compound functions as an antibiotic replacement. Prebiotic is one of natural compound without residue and is generally friendly for consumer's health. Prebiotic is defined as the undigested feed component and provide a positive impact to the host by stimulating growth through the activity of beneficial bacteria in the intestine (Choudhari et al., 2008). The prebiotic administration can be associated with the increase in the number and activity of Bifidobacteria and lactic acid bacteria (Lactobacillus) that provide beneficial effects for the host, particularly from the aspect of improving body resistance and immunity which leads to the improved productivity.

The natural source of prebiotic is the tuber of dahlia flower. Dahlia tuber contained inulin by $69.50 \%$ to $75.48 \%$ (Saryono et al., 1998; Wijanarka et al., 2004). Shivayogeppa et al. (2009) also stated that dahlia is tuber-producing plant containing the highest level of inulin, fructose as well as active compounds such as phytic and benzoic acids. Inulin is known as food ingredient and can be classified as the best prebiotic among others (Azhar, 2009). Chemical properties of inulin is water soluble and cannot be digested by digestive enzymes but can be fermented by intestinal microbes. Inulin serve as "feed ingredient" for Bifidobacteria and Lactobacilli because it can be easily and quickly fermented (Roberfroid, 2007).

In the intestine, inulin can be almost completely fermented into short chain fatty acids (SCFAs) by specific microbes producing lactic acid. This is in accordance with the report of Kelly (2008) that the fermentation products of inulin-type fructans are carbon dioxide, hydrogen, lactate, and SCFAs, including acetate, propionate, and butyrate. Previous in vivo and in vitro studies (Pool-Zobel, 2005) also support that inulin can be fermented by Bifidobacteria and Lactobacilli by producing SCFAs and L-lactate. Such condition causes a decrease in intestinal $\mathrm{pH}$ so that the growth of pathogenic bacteria is inhibited, on the other hand, beneficial bacteria, particularly Lactobacillus, can develop well. Such mechanism leads to the improvement of body resistance and affect chicken products related to the beneficial effect of prebiotics to promote the growth of lactic acid bacteria. According to Surono (2004), lactic acid bacterial cell membrane can bind to cholesterol in the small intestine before being absorbed into the body that finally decreases blood cholesterol. Previous research (Nabizadeh et al., 2012) showed that inulin derived from chicory roots at the level of $1 \%$ gave a positive effect on the health of the host animals which was characterized by a greater weight of bursa fabricius, as an indicator of the improved body resistance and immunity. Seifer \& Watzl (2007) has reported that function of Peyer's patches are known to be responsible to inulin or oligufructose suplementation in relation to intestinal imun system or immune cell accociated system on animal production. For instance, the suplementation of dietary prebiotic inulin in rats indicated the ability of stimulating the production of IL-10 by Peyer's patch cells, as indication of improved health status Roller et al. (2004). Guarner (2007) reported that the number of Salmonella typhimurium in the intestine was inhibited and the population of pathogenic bacteria in the Peyer's patch was significantly lower in rats fed inulin-oligofructose.

In addition to lymphoid organ weights, blood components, such as heterophile to lymphocyte ratio $(\mathrm{H} / \mathrm{L}$ ratio), is an indicator of the body resistance as a form of chickens response to unfavorable environmental factors. $\mathrm{The} \mathrm{H} / \mathrm{L}$ ratio is an indicator of stress in chickens which is closely related to the performance of bursa fabricius, because this organ is lymphocytes-forming place that plays a critical role body's immune system. According to Kusnadi (2008), the higher H/L ratio, the higher the level of stress as a manifestation of adaptation to the environmental conditions. The values of $\mathrm{H} / \mathrm{L}$ ratio in birds can be divided into 3 levels, namely low (0.2), normal (0.5), and high (0.8) (Emadi \& Kermanshahi, 2007). Inulin is known to be able to increase growth of lactic acid bacteria that secrete immunomodulator compound, a component that is able to interact with the immune system, and bring about stimulating or depressing effects on specific and nonspecific immune systems (Tzianabos, 2000). The immune response is a process of response generated by the cells and molecules that compose immune system after being faced with a foreign substance (antigen). The purpose of the present study was to evaluate the role of inulin as a prebiotic in an effort to improve body resistance and immunity, performance and product quality of crossbred local chickens.

\section{MATERIALS AND METHODS}

A total of 280 of crossbred local chicken (cross mating of male native chicken and female modern laying hen) aged $22 \mathrm{~d}$ with an average body weight of $180.46 \pm 1.21 \mathrm{~g}$ were used. Rations were composed of corn, rice bran, soybean meal, fish meal, $\mathrm{CaCO}_{3^{\prime}}$ minerals, vitamins, and dahlia flower tuber in the form of powder and extract. Powder and extract of dahlia tuber were homemade products which were prepared by the methods of Azhar (2009) with slight modification. Protein and energy contents of the experimental diets were 19\% and $2.800 \mathrm{kcal} / \mathrm{kg}$, respectively, for starter period, and $17 \%$ and $2.800 \mathrm{kcal} / \mathrm{kg}$, respectively, for finisher period (Table 1). Dietary treatments were provided for 9 wk starting on day 22 until day 77. The experimental chickens were given access ad libitum to ration and drinking water.

The experiment was assigned in a completely randomized design with 7 treatments and 4 replications (10 birds each). Treatments applied were as follows: T0: ration without powder or extract of dahlia tuber, $\mathrm{T} 1$ : ration $+0.4 \%$ powder of dahlia tuber, $\mathrm{T} 2$ : ration $+0.8 \%$ powder of dahlia tuber, T3: ration $+1.2 \%$ powder of dahlia tuber, T4: ration $+0.39 \%$ extract of dahlia tuber, T5: ration $+0.78 \%$ extract of dahlia tuber, $\mathrm{T} 6$ : ration $+1.17 \%$ extract of dahlia tuber. Determination of the level of powder and extract of dahlia tubers as inulin source was based on the previous research conducted by Nabizadeh (2012) who was found that the best inulin level was $1 \%$ in broiler chicken. Therefore, it was created 
Table 1. Composition and nutritional contents of experimetal diet based on as fed

\begin{tabular}{lrr}
\hline Feed ingredient (\%) & \multicolumn{1}{c}{ Starter } & Finisher \\
\hline Yellow Corn & 51.30 & 47.00 \\
Rice Bran & 15.00 & 25.00 \\
Soybean Meal & 22.50 & 18.00 \\
Fish Meal & 10.00 & 8.00 \\
$\mathrm{CaCO}_{3}$ & 0.70 & 1.20 \\
Vitamin and Mineral & 0.50 & 0.80 \\
Total & 100.00 & 100.00 \\
Nutritional Content $(\%)^{*}:$ & & \\
Metabolizable energy (kcal/kg) & \\
Crude protein & 2821.89 & 2872.80 \\
Ether extract & 19.46 & 17.56 \\
Crude fiber & 4.99 & 5.75 \\
Calcium & 4.81 & 5.94 \\
Posphorus (total) & 1.02 & 1.01 \\
Methionine & 0.66 & 0.64 \\
Methionine + Cystine $^{* * *}$ & 0.44 & 0.39 \\
Lysine $^{* * *}$ & 0.09 & 0.08 \\
Arginine $^{* * *}$ & 1.26 & 1.08 \\
\hline
\end{tabular}

Note: "Based on calculation using the formula of Hartadi et al. (2005); **Results of proximate analysis at the Laboratory of Nutrition and Feed Science, Faculty of Animal Science and Agriculture. Diponegoro University; ${ }^{* * *}$ Based on Table NRC (1994).

3 levels, namely low, medium and high, according to the analysis results of inulin content which was found to be $86.27 \%$ for powder and $88.95 \%$ for extract. Parameters measured were lymphoid organs (weights of bursa fabricius and spleen), heterophile-lymphocyte ratio $(\mathrm{H} / \mathrm{L}$ ratio), meat lipid profiles and body weight gain (BWG). Lymphoid organs were calculated according to the following equation:

Lymphoid Organs Weight $(\%)=$ [Lymphoid Organs Weight (g)/Liveweight (g)] x 100\%

Heterophile and lymphocytes were assessed on day 77 by taking the blood samples of birds about 0.5 to 1 $\mathrm{mL}$ into the EDTA-containing tubes through branchialis vein. Lymphoid organs were also dissected and weighed at the same age. To obtain heterophile-lymphocyte ratio, blood samples were smeared on glass slide. The smears were stained by using may-grundwald and giemsa stains, approximately 2-4 h after methylalcohol fixation. One hundred leucocytes including granular (heterophile, eosinophil, and basophiles) and nongranular (lymphocytes and monocytes) were counted and the heterophile to lymphocyte ratio were calculated (Nabizadeh et al., 2012). Meat cholesterol contents were determined by Leibermann and Burchard method, by using spectrophotometer at a wavelength of $680 \mathrm{~nm}$ (Fathullah et al., 2013). Data were subjected to analysis of variance (ANOVA) and continued to Duncan's test (Steel \& Torrie, 1991) at 5\% probability. Orthogonal polynomial test was also applied to determine the optimal point of powder and extract levels of dahlia tuber as inulin source (Gazperz, 1998).

\section{RESULTS AND DISCUSSION}

The mean relative weights of bursa fabricius and spleen and the mean value of $\mathrm{H} / \mathrm{L}$ ratio due to the inclusion of powder and extract of dahlia flower tuber are presented in Table 2. Powder and extract of dahlia tuber significantly $(\mathrm{P}<0.05)$ affected weight of bursa fabricius and $\mathrm{H} / \mathrm{L}$ ratio, but not on the weight of the spleen. Inclusion of inulin in the form of powder or extract (T2, T3, T5, and T6) produced significantly $(\mathrm{P}<0.05)$ higher weights of bursa fabricius as compared to control (T0), but there was no difference among the treatments of T1, T4, and T0 (Table 2). Values of the $\mathrm{H} / \mathrm{L}$ ratio also indicated a similar condition that the addition of powder and/or extract of dahlia tuber (T1, T2, T3, T5, and T6) significantly $(\mathrm{P}<0.05)$ decreased $\mathrm{H} / \mathrm{L}$ ratio as compared to control (T0) and it was still within the normal range, while $\mathrm{H} / \mathrm{L}$ ratio in the $\mathrm{T} 0$ and T4 treatments were high (Table 2). The higher value of $\mathrm{H} / \mathrm{L}$ ratio especially in chicken fed the lowest level of powder (T4) might be due to the process of adaptation known as "self phagocytosis" of beneficial bacteria onto pathogenic microbes since T4 group received lower inulin and also low carbohydrates. However, there was no change in the weight of spleen due to the feeding of inulin source derived from dahlia tuber.

It can be assumed that body resistance was less improved which was indicated by the low weight of bursa fabricius and high value of $\mathrm{H} / \mathrm{L}$ ratio, due to the low levels of feeding inulin source either in the form of powder or extract of dahlia tuber. In contrast, other treatments with higher levels of either powder (T3) or

Table 2. Weight percentage of lymphoid organs (spleen and bursa fabricius) and heterophile-lymphocyte ratio in crossbred local chicken

\begin{tabular}{cccc}
\hline Treatment & Bursa fabricius (\%) & Spleen (\%) & H/L Ratio \\
\hline T0 & $0.12 \pm 0.02^{\mathrm{d}}$ & $0.30 \pm 0.14$ & $0.89 \pm 0.08^{\mathrm{a}}$ \\
T1 & $0.21 \pm 0.10^{\mathrm{bcd}}$ & $0.30 \pm 0.10$ & $0.75 \pm 0.11^{\mathrm{b}}$ \\
T2 & $0.31 \pm 0.13^{\mathrm{ab}}$ & $0.24 \pm 0.07$ & $0.68 \pm 0.12^{\mathrm{b}}$ \\
T3 & $0.33 \pm 0.06^{\mathrm{a}}$ & $0.22 \pm 0.04$ & $0.66 \pm 0.09^{\mathrm{b}}$ \\
T4 & $0.20 \pm 0.13^{\mathrm{cd}}$ & $0.26 \pm 0.12$ & $0.88 \pm 0.07^{\mathrm{a}}$ \\
T5 & $0.30 \pm 0.09^{\mathrm{abc}}$ & $0.28 \pm 0.10$ & $0.68 \pm 0.07^{\mathrm{b}}$ \\
T6 & $0.31 \pm 0.05^{\mathrm{abc}}$ & $0.28 \pm 0.13$ & $0.67 \pm 0.10^{\mathrm{b}}$ \\
\hline
\end{tabular}

Note: means in the same columns with different superscripts differ significantly $(\mathrm{P}<0.05)$. T0: ration without powder or extract dahlia tuber. T1: ration $+0.4 \%$ powder of dahlia tuber. T2: ration $+0.8 \%$ powder of dahlia tuber. T3: ration $+1.2 \%$ powder of dahlia tuber. T4: ration $+0.39 \%$ extract of dahlia tuber. T5: ration $+0.78 \%$ extract of dahlia tuber. T6: ration $+1.17 \%$ extract of dahlia tuber. 
extract (T6) could improve body resistance since the weight of bursa fabricius markedly increased with the normal value of H/L ratio. Tizzard (1988) stated that the birds with higher relative weight of bursa fabricius, were more resistant to the effects of unfavorable environment. This phenomenon was supported by the main function of heterophile to crush and destroy substances and metabolite products produced by pathogenic bacteria. The immediate work of heterophile known as the first line of resistance is the immune system process. According to Emadi \& Kermanshahi (2007), the level of body resistance of the birds can be determined by the value of the H/L ratio, namely low (0.2), normal (0.5) and high (0.8). The $\mathrm{H} / \mathrm{L}$ ratio found in the present study can be compromised as normal level, namely 0.66 (T3) and 0.67 (T6), due to the feeding effect of dietary inclusion of either powder or extract of dahlia tuber at higher levels. It was suggested that the inulin treatment was able to increase the bird's stamina as responses to the change in environment condition, especially when they were reared in the open house system.

Bursa fabricius is a primary lymphoid organ functions as humoral antibody that responsible for the development and maturation of B-lymphocytes, and it will give response when the foreign substances or antigens interfere with the body (Zhang et al., 2006; Cheema et al., 2007; Mahrous et al., 2008), which then circulate into the bloodstream and react against foreign substances that enter the body. The $\mathrm{H} / \mathrm{L}$ ratio is closely related to the bursa fabricius's function because this organ is lymphocyte-forming place and exerts the principle function in the body's immune system to prevent stress response due to unfavorable environment (Apriliyani et al., 2013). This is in accordance with the previous report
(Yalcinkaya et al., 2008) that the lymphocytes are crucial elements on the immune system, which functions to give respond to antigens by forming antibodies. Orthogonal polynomial test showed a linear pattern with the best results indicated by the addition of $1.2 \%$ powder and $1.17 \%$ extract forms (Figure 1). However, the higher level of inulin sources administration in the form of either powder or extract, the lower value of $\mathrm{H} / \mathrm{L}$ ratio was observed, and it was still within the normal range. The decrease in the ratio of $\mathrm{H} / \mathrm{L}$ was in accordance with the normal standard (0.5), and $50 \%$ of the value was influenced by the inclusion of powder form and $58 \%$ was affected by extract form (Figure 2).

Different case was found with the relative weight of the spleen that was not significantly $(\mathrm{P}>0.05)$ affected by the treatments (Table 2). The weight of spleen was not statistically different, but numerically the control (T0) and low inulin powder of $0.4 \%$ (T1) showed the tendency of higher value as compared to that of other treatments. The slightly higher spleen weight could be assumed that there was more antigens entered into the spleen and further stimulated the spleen to work harder which led to the increase in size. It is supported by the finding of Yunus et al. (2008) that the traits of active spleen is microscopically characterized by the presence of lymphocytes proliferation, while macroscopically can be viewed from the increase in size and weight. The spleen is a major site of phagocytes to take antibody-bound antigen, then the antigens were cleared by macrophages in the spleen. Thus, the spleen is the main point of the immune system response to antigens derived from the blood filter. Conversely, in other treatments, either with powder or extract, spleen weights were numerically lower, so it can be stated that

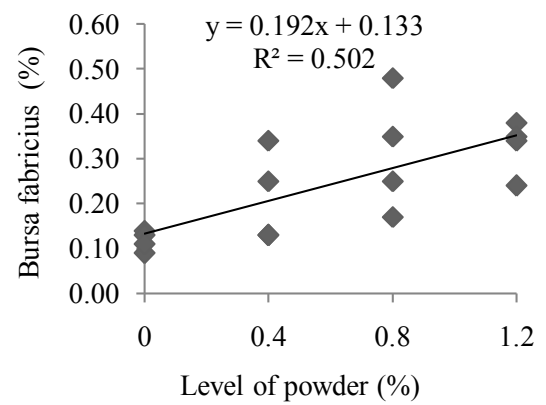

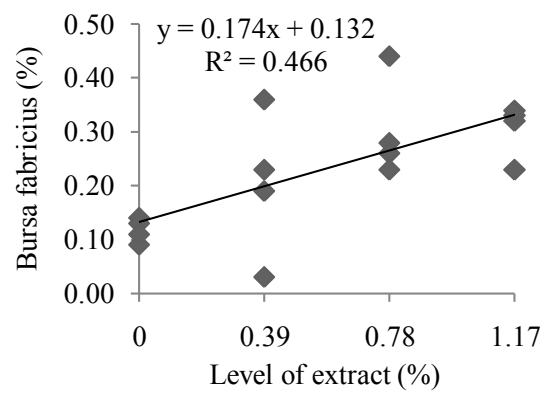

Figure 1. The graph of polynomial pattern of inulin effect on bursa fabricius. (a) treatment of powder, (b) treatment of extract.

a

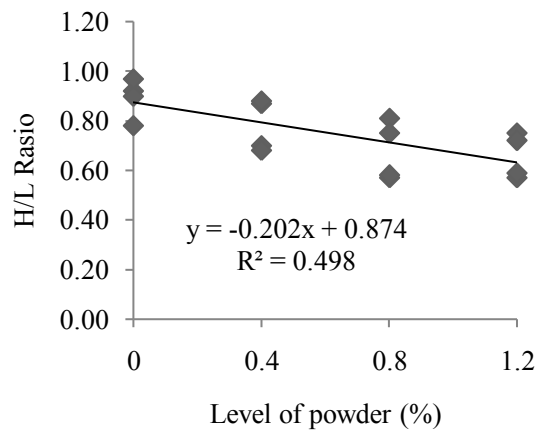

b

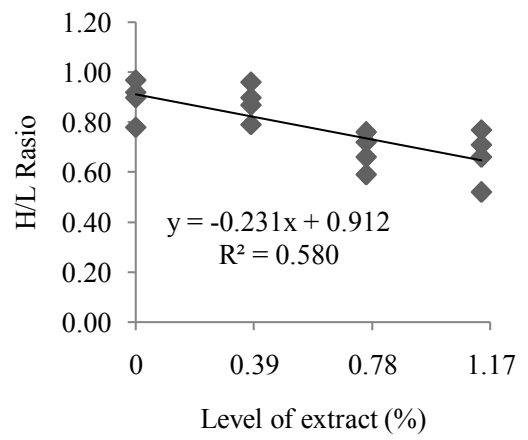

Figure 2. The graph of polynomial pattern of inulin effect on H/L ratio (a) treatment of powder, (b) treatment of extract. 
the inulin treatment could slightly improve the health of chickens because macrophages could kill antigen prior to the entry into the bloodstream. Finally, the impact of the reduction of antigens reduces the work of the spleen and results in lower weight than those of T0 and T1. This is consistent with the finding of Bikrisma et al. (2013) that broiler with large spleen indicating the chickens suffered stress due to unfavorable environment. This condition indirectly affected the spleen's works in body resistance and immunity via the increase in lymphocytes production and ultimately affected the size of the spleen. This condition was contradictory with the higher weights of bursa fabricius in chicken treated with powder and extract of dahlia tuber than control (T0). This result implied that bursa fabricius was able to take over the role in anticipating the entry of the antigen and finally brought about the slightly lower weight of the spleen.

Aspect of health condition is strongly associated with the production capability, i.e. growth performance. The following discussion is dealing with the quality of productive characteristics in case of meat lipid profiles (fat and cholesterol contents) as well as body weight gain/BWG (Table 3). Meat fat content showed a slightly different phenomenon than meat cholesterol. Meat fat decreased significantly $(\mathrm{P}<0.05)$ and lower than the control due to the inclusion of all levels of both powder and extract dahlia tuber as a source of inulin. However, cholesterol content of meat in chickens treated with powder and extract administration at a low level (T1 and T4) was similar as compared to control, but other treatments markedly decreased. The decreasing levels of fat and cholesterol of meat due to the treatments with powder and extract (Table 3) was in line with the increase in the number of lactic acid bacteria (LAB) in the duodenum. Population of LAB was $1.28 \times 10^{4}$ when fed powder form (T2), and the highest value was $2.5 \mathrm{x}$ $10^{4}$ with extract form (T6) but the lowest was $1.18 \times 10^{4}$ for control (T0) (Krismiyanto, unpublished data).

The phenomenon found in the present study provided evidence that the function of inulin in improving health status was through a decrease in the $\mathrm{pH}$ of the gastrointestinal tract that increased the number of beneficial bacteria in particular lactic acid bacteria. Musatto (2007) reported that beneficial bacteria in the gut were generally derived from Lactobacillus and Bifidobacteria and functions in the formation of short chain fatty acids (SCFA), namely acetate, propionate and butyrate. This mechanism has implications for meat production in relation to the reduction in cholesterol level. According to Surono (2004), feeding inulin was known to be able to enhance the growth of lactic acid bacteria and exerted its effect on the mechanism in lowering cholesterol by producing enzymes of bile salt hydrolase (BSH) through the process of bile acids deconjugation, into the form of free cholate acid, and brought about the decreased cholesterol absorption in the intestine. Deconjugated bile salts are more easily excreted together through feces, so that a part of blood cholesterol is used to form and recover bile salts which further led to the decrease in the level of cholesterol in the blood and with a final result in low meat cholesterol. This fact is supported by Tannock (1999) that the cholesterol-lowering mechanism due to the lactic acid bacteria is able to degrade cholesterol to coprostanol, a sterol that cannot be absorbed by the intestine. Furthermore, coprostanol and the remaining cholesterol are removed along with excreta, so that the amount of cholesterol absorbed into the blood is decreased. The decrease in meat fat content was occurred due to the inclusion of inulin related to the increased non-pathogenic bacteria population and decreased number of pathogenic bacteria. Improvement of bacterial balance causes healthier digestive tract and leads to an increase in overall animal health. The decrease in fat and cholesterol of meat is described by a linear-shaped curve (Figure 3 and 4, respectively), this provides the meaning that the higher the level of additional inulin in the form of either starch or extract, the lower the fat and cholesterol deposited in the meat of crossbred local chicken.

Inulin in the form of powder and extract were also able to increase body weight gain (Table 3). Feeding of inulin increased the number of lactic acid bacteria in order to create a healthy digestive tract, which condition had an important impact on the increase in nutrient digestibility, especially protein. It was observed that dietary protein digestibility at the ileum level increased to a higher level by $52.87 \%$ with powder form (T3) and by $55.35 \%$ with extract form (T6) as compared to control (T0) that was only $48.92 \%$ (Fanani, unpublished data). The high protein digestibility was supported by the high nitrogen retention value due to the dietary inclusion of powder (1.50 g in T3) and extract (1.69 $\mathrm{g}$ in T6), while control group had the lowest level (only $1.28 \mathrm{~g}$ ) (Fanani, unpublished data). The higher nitrogen retention indicates the higher protein deposition with a final result in high muscle protein mass and BWG (Maharani et al.,

Table 3. Meat lipid profiles and body weight gain of crossbred local chickens fed inulin derived from dahlia flower tuber

\begin{tabular}{|c|c|c|c|}
\hline Treatments & Meat fat $(\%)$ & Meat cholesterol (mg/dl) & BWG (g/bird) \\
\hline T0 & $4.57 \pm 0.72^{\mathrm{a}}$ & $9.06 \pm 2.60^{a}$ & $714.09 \pm 39.58^{\mathrm{d}}$ \\
\hline $\mathrm{T} 1$ & $3.16 \pm 0.30^{b}$ & $7.07 \pm 1.35^{\mathrm{ab}}$ & $818.05 \pm 15.85^{c}$ \\
\hline $\mathrm{T} 2$ & $3.19 \pm 0.53^{b}$ & $5.79 \pm 1.08^{\mathrm{b}}$ & $831.55 \pm 14.67^{\mathrm{bc}}$ \\
\hline $\mathrm{T} 3$ & $1.82 \pm 0.18^{c}$ & $5.87 \pm 1.07^{\mathrm{b}}$ & $851.70 \pm 59.48^{\mathrm{abc}}$ \\
\hline $\mathrm{T} 4$ & $2.97 \pm 0.67^{b}$ & $7.11 \pm 1.5^{\mathrm{ab}}$ & $864.07 \pm 34.18^{\mathrm{ab}}$ \\
\hline T5 & $2.10 \pm 0.64^{c}$ & $5.84 \pm 1.13^{\mathrm{b}}$ & $876.71 \pm 24.95^{\mathrm{ab}}$ \\
\hline $\mathrm{T} 6$ & $1.66 \pm 0.28^{c}$ & $5.02 \pm 3.53^{\mathrm{b}}$ & $885.90 \pm 55.64^{\mathrm{a}}$ \\
\hline
\end{tabular}

Note: means in the same columns with different superscripts differ significantly $(\mathrm{P}<0.05)$. T0: ration without powder or extract dahlia tuber. T1: ration $+0.4 \%$ powder of dahlia tuber. T2: ration $+0.8 \%$ powder of dahlia tuber. T3: ration $+1.2 \%$ powder of dahlia tuber. T4: ration $+0.39 \%$ extract of dahlia tuber. T5: ration $+0.78 \%$ extract of dahlia tuber. T6: ration $+1.17 \%$ extract of dahlia tuber. 
2013). BWG was closely related to the muscle protein mass and it was observed that there was a numerically increase in muscle protein by $51.64 \mathrm{~g}$ in chickens treated with powder (T3) and by $53.77 \mathrm{~g}$ in those treated with extract (T6) of dahlia flower tuber as compared to control (T0) that was only reached $48.85 \mathrm{~g}$ (Fanani, unpublished data). This phenomenon gave the assumption that the nutrient, especially protein utilization was efficiently improved by the dietary inclusion of dahlia tuber as inulin source.

The increasing BWG was attributable to protein utilization and health status, indicated by $\mathrm{H} / \mathrm{L}$ ratio (Table 2) when inulin in the forms of powder and extract were fed. Increased chicken's health would decrease the utilization of protein for tissue repair and antibodies formation that eventually increased the deposition protein into the muscle (Jamilah et al., 2013) due to the improved nitrogen retention (Ma'rifah et al., 2013), and higher rate of muscle protein synthesis than degradation (Suthama, 2006). The increase in BWG was indicated by a linear curve (Figure 5). This patterns indicates that the higher level of powder and extract inclusions, the greater effect on BWG stimulation. The result of this study agreed with Nabizadeh (2012) that body weight increased significantly when $1 \%$ inulin was added and was also supported by Rebole et al. (2010) that the inclusion of inulin at the levels of $10 \mathrm{~g}(1 \%)$ and $20 \mathrm{~g}$ $(2 \%)$ per $\mathrm{kg}$ in wheat and barley-based rations increased the body weight of broilers.

\section{CONCLUSION}

The higher levels of dietary inclusion of dahlia flower tuber either in the form of powder at 1.2\% (T3)
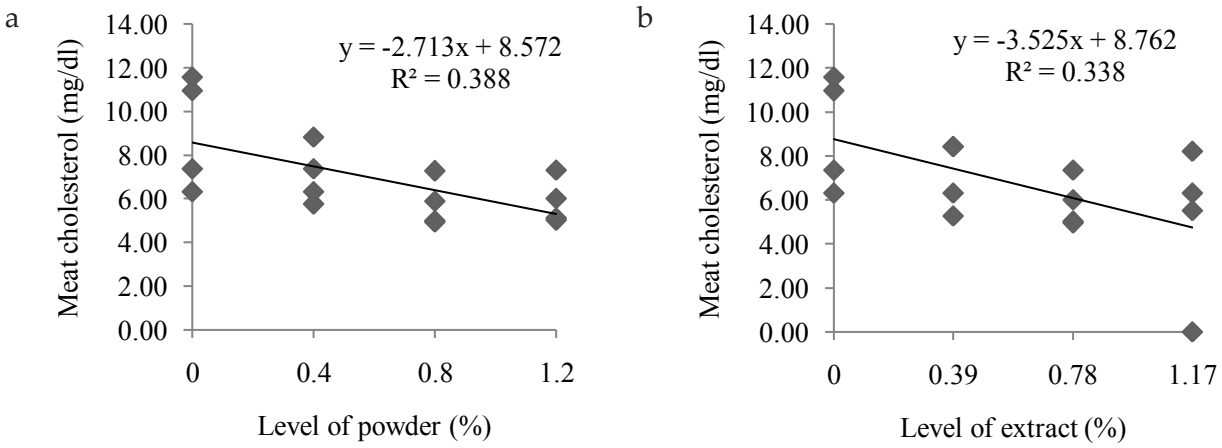

Figure 3. The graph of polynomial pattern of inulin effect on meat cholesterol (a) treatment of powder, (b) treatment of extract.
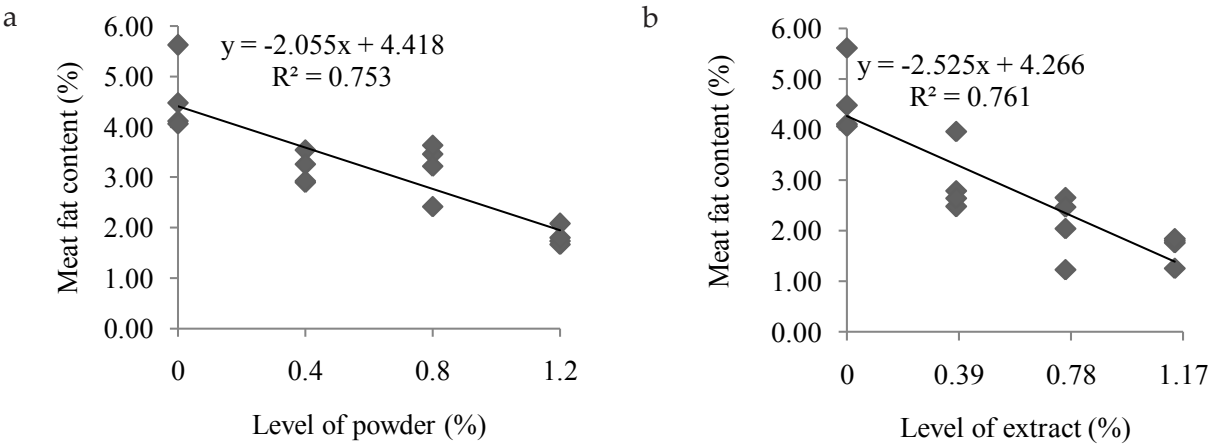

Figure 4. The graph of polynomial pattern of inulin effect on meat fat content (a) treatment of powder, (b) treatment of extract.
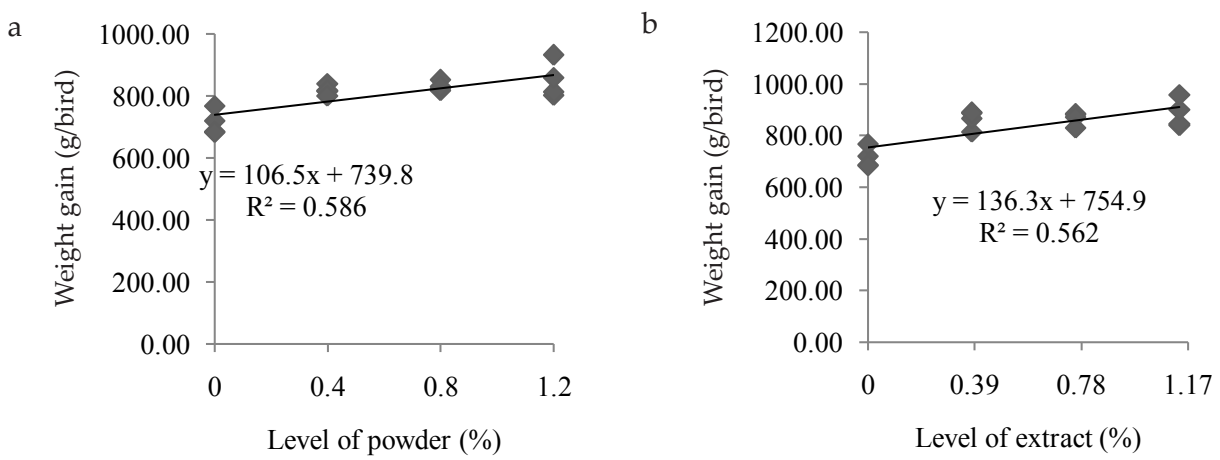

Figure 5. The graph of inulin effect on weight gain (a) treatment of powder, (b) treatment of extract 
or extract at $1.17 \%$ (T6) as inulin source improve health status, body weight and product quality of crossbred local chicken.

\section{REFERENCES}

Apriliyani, F., N. Suthama, \& H. I. Wahyuni. 2013. Rasio heterofil limfosit dan bobot relatif bursa fabrisius akibat kombinasi lama pencahayaan dan pemberian porsi ransum berbeda pada ayam broiler. J. Anim. Agric. 2: 393-399.

Azhar, M. 2009. Inulin sebagai prebiotik. J. Sainstek. 12: 23-26.

Bikrisima, S. H. L., Mahfudz L. D, \& N. Suthama. 2013. Ketahanan tubuh ayam broiler pada kondisi tropis yang diberi jambu biji merah (psidium guajava) sebagai sumber antioksidan. AGROMEDIA 31: 46-57

Cheema, M. A., M. A. Qureshi, G. B. Havenstein, P. R. Ferket, \& K. E. Nestor. 2007. A comparison of the immune response of 2003 commercial turkeys and a 1966 randombred strain when fed representative 2003 and 1966 turkey diets. Poult. Sci. 86: 241-248. http://dx.doi.org/10.1093/ps/86.2.241

Choudhari, A. S., Shinde, \& B. N. Ramteke. 2008. Prebiotics and probiotics as health promoter. Vet. World. $1: 59-6$.

Emadi, M. \& H. Kermanshahi. 2007. Effect of varying level of tumeric rhizome powder on some blood parameters of broiller chikens fed corn-soybean meal based diet. Int. J. Poult. Sci. 6: 345-348. http://dx.doi.org/10.3923/ ijps.2007.345.348

Fathullah., N. Iriyanti, \& I. H. Sulistiyawan. 2013. Penggunaan pakan fungsional dalam ransum terhadap bobot lemak abdomen dan kadar kolesterol daging ayam broiler. J. Ilmiah Peternakan. 1: 119-128.

Gaspersz, V. 1998. Statistical Process Control. Gramedia Pustaka Utama, Jakarta.

Guarner, F. 2007. Studies with inulin-type fructans on intestinal infections, permeability, and inflammation. J. Nutr. 137: 2568S-2571S.

Hartadi, H., S. Reksohadiprodjo, \& A. D. Tillman. 2005. Tabel Komposisi Pakan untuk Indonesia. Gadjah Mada University Press, Yogyakarta.

Jamilah, N. Suthama, \& L. D. Mahfudz. 2013. Performa produksi dan ketahanan tubuh broiler yang diberi pakan step down dengan penambahan asam sitrat sebagai acidifier. JITV. $18: 251-257$.

Kelly, G. 2008. Inulin-type prebiotics--a review: part 1. Altern. Med. Rev. 13:315-329.

Kusnadi, E. 2008. Pengaruh temperatur kandang terhadap konsumsi pakan dan komponen darah broiler. J. Indon. Trop. Anim. Agric. 33:197-202.

Maharani, P., N. Suthama, \& H. I. Wahyuni. 2013. Massa kalsium dan protein daging pada ayam arab petelur yang diberi ransum menggunakan Azolla microphylla. J. Anim. Agric. 2 : 18-27.

Mahrous, M., A. Galal., M. M. Fathi, \& A. Z. El-Dein. 2008. Impact of naked neck $(\mathrm{Na})$ and frizzle $(\mathrm{F})$ genes on growth performance and immunocompetence in chickens. Int. J. Poult. Sci. 7: 45-54. http://dx.doi.org/10.3923/ ijps.2008.45.54

Ma'rifah, B., U. Atmomarsono, \& N. Suthama. 2013. Nitrogen retention and productive performance of crossbred native chicken due to feeding effect of kayambang (Salvinia molesta). Int. J. Sci. Eng. 5:19-24. http://dx.doi.org/10.12777/ ijse.5.1.19-24

Musatto, S. I. \& I. M. Mancilha. 2007. Non-digestible oligosaccharide: a review. J. Carbohydrate Polymer. 68: 587-597. http://dx.doi.org/10.1016/j.carbpol.2006.12.011

Nabizadeh, A., O. Gevorkyan \& A. Golian. 2012. Effect of inulin on some hematological, immunological parameters and broiler chickens performance. J. Anim. Vet. Adv. 11: 3304-
3311. http://dx.doi.org/10.3923/javaa.2012.3304.3311

Nabizadeh, A. 2012. The effect of inulin on broiler chicken intestinal microflora, gut morphology, and performance. J. Anim. Feed Sci. 21: 725-734.

National Research Council. 1994. Nutrient Requirements of Poultry. 9th Revised Edition. National Academic Press, Wahington DC.

Pool-Zobel, B. L. 2005. Inulin type fructans and reduction in cancer risk : review of experimental and human data. Br. J. Nutr. 93 (Suppl 1) : S73-S90. http://dx.doi.org/10.1079/ BJN20041349

Rebole, A., L. T. Ortiz., M. L. Rodriguez., C. Alzueta., J. Trevino, \& S. Velasco. 2010. Effects of inulin and enzyme complex, individually or in combination, on growth performance intestinal microflora, cecal fermentation characteristics and jejunal histomorphology in broiler chickens fed a wheat and barley-based diet. Int. J. Poult. Sci. 89: 276278. http://dx.doi.org/10.3382/ps.2009-00336

Roberfroid, M. B. 2007. Prebiotics : the concept revisited. J. Nutr. $137: 830-837$.

Roller, M., G. Rechkemmer, \& B. Watzl. 2004. Prebiotic inulin enriched with oligofructose in combination with the probiotics Lactobacillus rhamnosus and Bifidobacterium lactis modulates intestinal immune functions in rats. J. Nutr 134: 153-156

Saryono, P. Sulistyati, Z. Delita, \& A. Martna. 1998. Identifikasi jamur pendegradasi inulin pada rizosfir umbi dahlia (Dahlia variabilis). J. Natur Ind. 11: 22-27.

Seifert, S. \& B. Watzl. 2007. Inulin and oligofructose: review of experimental data on immune modulation. J. Nutr. 137 : 2563S-2567S

Shivayogeppa, J., A. Dinakara., G. Prabhuling., B. S. Reddy., S. K Natraj \& S. J. Prashanth. 2009. In vitro conservation studies in dahlia (Dahlia variabilis). Asian. J. Hort. 4: 470472

Steel, R. G. D, \& J. H. Torrie. 1991. Prinsip dan Prosedur Statistika Suatu Pendekatan Biometrik. Cetakan kedua. PT. Gramedia Pustaka Tama, Jakarta.

Surono, I. S. 2004. Probiotik: Susu Fermentasi dan Kesehatan. PT. Tri Cipta Karya, Jakarta.

Suthama, N. 2006. Kajian aspek "protein turnover" tubuh pada ayam kedu periode pertumbuhan. Med. Pet. 29: 47-53.

Tannock, G. W. 1999. The Normal Microflora: An Introduction. In Medical Importance of The Normal Microflora. Springer, US. pp. 1-23.

Tizard, T. R. 1988. Pengantar Imunologi Veteriner. Airlangga University Press. Surabaya.

Tzianabos, A. O. 2000. Polysaccharides immunomodulatory as therapeutic agents : structural aspect and biological function. Clin. Microbiol. Rev. 523-533. http://dx.doi. org/10.1128/CMR.13.4.523-533.2000

Wijanarka., R. S. Ferniah, \& Salamah. 2004. Produksi inulinase Pichia alni ducc-w4 pada tepung umbi dahlia (Dahlia variabilis willd) dengan variasi konsentrasi ammonium nitrat dan waktu inkubasi. BIOMA 10 : 58-64.

Yalcinkaya, L., T. M. Gonggor, Basalan, \& E. Erdem. 2008. Mannan oligosaccharides (MOS) from Saccharomyces cerevisiae in broilers: Effects on performance and blood biochemistry. Turk. J. Vet. Anim. Sci. 32 : 43-48.

Yunus, M., L. T. Suwanti, I. Mustofa, \& V. Hardiani. 2008. Pengaruh infeksi Eimeria tenella terhadap berat, ukuran limpa dan diameter pulpa putih pada ayam infeksi primer dan sekunder. Vet. Medika. 1: 13-16.

Zhang, H. M., H. D. Hunt, G. B. Kulkarni, D. E. Palmquist, \& L. D. Bacon. 2006. Lymphoid organ size varies among inbred lines 63 and 72 and their thirteen recombinant congenic strains of chickens with the same major histocompatability complex. Poult. Sci. 85: 844-853. http://dx.doi. org/10.1093/ps/85.5.844 